\title{
WOODHEAD PUBLISHING SERIES IN CIVIL AND STRUCTURAL ENGINEERING
}

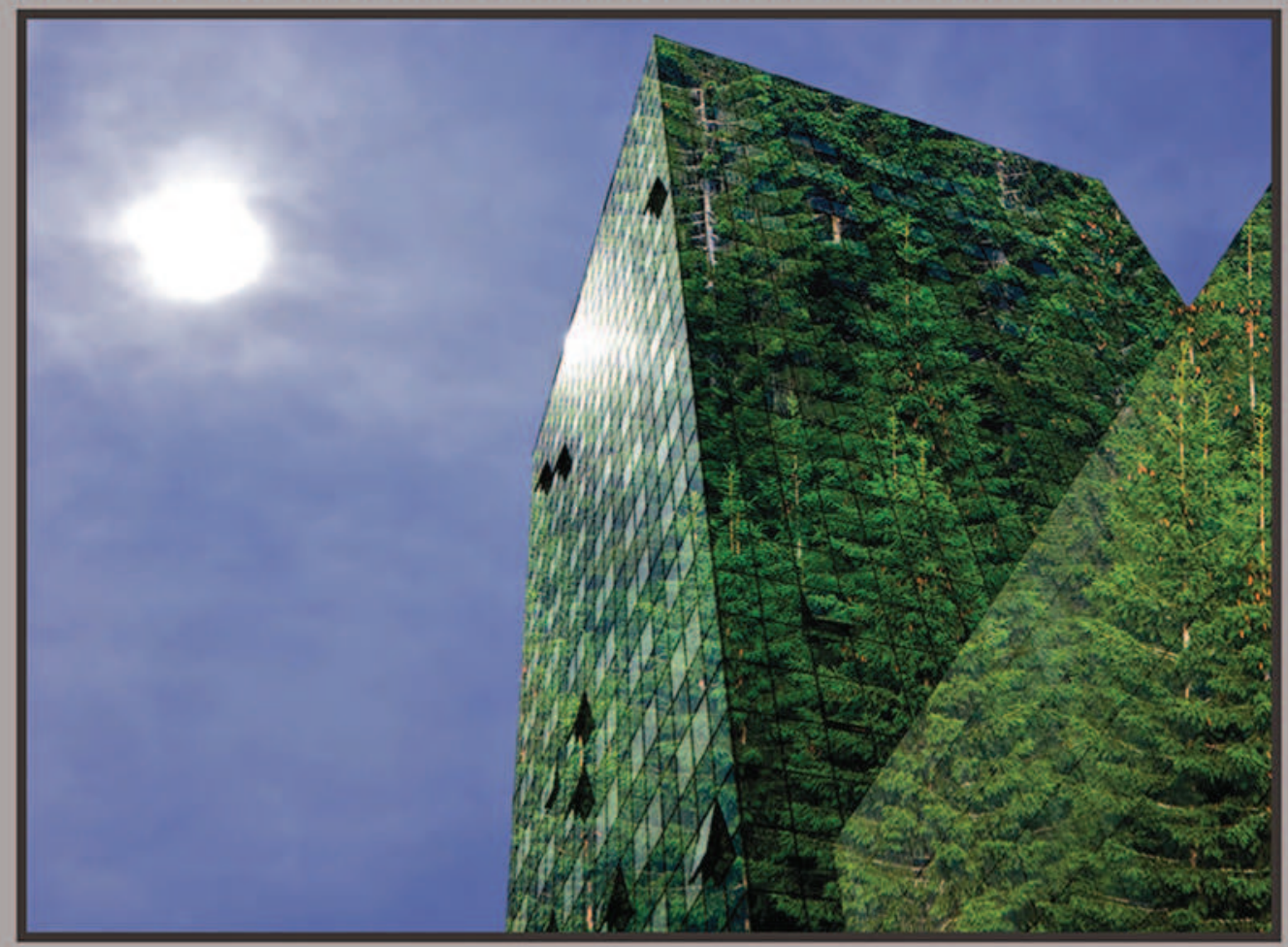

\section{BIO-BASED MATERIALS AND BIOTECHNOLOGIES FOR ECO-EFFICIENT CONSTRUCTION}

Edited by FERNANDO PACHECO-TORGAL VOLODYMYR IVANOV DANIEL C.W. TSANG 


\title{
Introduction to biobased materials and biotechnologies for eco-efficient construction
}

\author{
F. Pacheco-Torgal
}

C-TAC Research Centre, University of Minho, Campus de Azurem, Guimarães, Portugal

\subsection{Sustainability challenges, resource efficiency, and the bioeconomy}

A world of limited resources aggravated by unsustainable living patterns and a growing population inevitably force us to seek sustainable new ways of production and consumption. The signs of that unsustainability are numerous, for instance from 1970 to 2010, annual global extraction of materials grow from 22 billion to 70 billion tonnes (Ekins and Hughes, 2017). Also biodiversity is being pushed toward degradation and possible collapse (Davis et al., 2018; Harrison et al., 2018). Furthermore, energy consumption has been steadily rising in the last decades and will keep on rising no matter what would be the situation (King et al., 2015). This is due not only to the increase in world population but also to the fact that electricity consumption per capita in low- and middle-income countries will increase as a consequence of future higher income and related higher comfort standards. And this is aggravated by the fact that only $21 \%$ of world electricity generation was from renewable energy in 2011 with a projection for nearly 25\% in 2040 (IEA, 2017). Maybe that can have something to do with the fact that fossil fuels are receiving subsidies of around $\$ 260$ billion per annum, nearly twice the subsidy to renewables (IEA, 2017). And despite the fact that installed capacity of renewable energy is growing and it set a new record of $161 \mathrm{GW}$ in 2015, the fact is that ExxonMobil predicts that all renewables will supply a minor share of global power generation by 2040 (Bai et al., 2018). As a consequence some authors (Stoknes and Rockström, 2018) are very pessimistic and believe that such low ambitious approach is not compatible with the ecologic limits of the Planet. Randers et al. (2018) on the other hand state that the world will not reach all sustainable development goals by 2030, nor even by 2050. More recently Hickel (2019), using data provided by O'Neill et al. (2018), stated that for rich nations to fit within the boundaries of the safe and just space needed for the world's nations to achieve key minimum thresholds in social welfare while remaining within planetary boundaries will require that rich nations need to abandon growth as a policy objective. Also Holford (2018) reminds us that technology not only has control on humans but also that which is driven by the neoliberal socioeconomic quest for profit maximization 
and economic growth. No wonder then that some may think that only a severe shutdown of the main carbon polluters could have meaning results (Bendell, 2018; Read, 2018) still they seem to forget that such action would have a major impact on the increase of poverty. Be there as it may and while no wonder solutions are found then that incremental improvements are the only short-term solution for the problem. In order to keep economy running, several institutions such as UNEP, World Bank, or the European Commission thus claim for green economy and green growth, which are expected to do more with less while improved human well-being and social equity. This was the rationale that led to the concept of eco-efficiency that was first coined in the book "Changing Course" (Schmidheiny and Business Council for Sustainable Development, 1992) in the context of 1992 Earth Summit process that is a more realistic approach than the well-known concept of sustainable development defined in the Bruntland Report (1987) as "development that meets the needs of the present without compromising the ability of future generations to meet their own needs." On this critical context the European Union (EU) has long ago assumed a leading role toward a more sustainable future. The Europe 2020 Strategy and its flagship initiative on "a resource efficient Europe" (COM, 2011b) set the EU on the path to this transformation. The flagship called for a roadmap "to define medium and long term objectives and means needed for achieving them." The Roadmap to a resource efficient Europe (COM, 2011a) proposes a new pathway to action on resource efficiency involving all the key stakeholders. Domenech and Bahn-Walkowiak (2019) argue that the resource efficiency and circular economy policy is complex and fragmented and they even say that the decoupling of resource use from economic growth although being a part of the vision drawn by the EU resource efficiency roadmap has not been addressed directly by specific policy instruments. The recent years have witnessed an increasing demand for natural, bio-, or biotech-based products for use in industrial applications because of environmental issues, waste disposal problems, and the depletion of nonrenewable resources. In 2002 the EU launched the strategy on biotechnology (EU, 2002). And in 2012 The European Commission created the world's first bioeconomy strategy and action plan (Bioeconomy Strategy, 2012). Bioeconomy is defined as "an economy where the basic building blocks for materials, chemicals, and energy are derived from renewable biological resources." More information can be found in Patermann and Aguilar (2018), Ramcilovic-Suominen and Pülzl (2018), and Schanes et al. (2019). The bioeconomy covers all sectors and systems that rely on biological resources (animals, plants, microorganisms, and derived biomass, including organic waste), their functions and principles. For instance the Europeans throw away more than 88 million tons of food every year. A new Estonian project wants every gram of it to be used to manufacture bioplastics and eco-friendly cosmetics (Zubascu, 2019). And with a turnover value of $€ 2.3$ trillion and accounting for $8.2 \%$ of the EU's workforce, the bioeconomy is a central element to the functioning and success of the EU economy. According to the new strategy, the bioeconomy will provide support for the modernization and strengthening of the EU industrial base through the creation of new value chains and greener, more cost-effective industrial processes. And according to industry projections, the demand for 
industrial biotechnologies is expected to almost double within the next decade. Demand for biobased products is growing worldwide and EU demand is estimated to grow to 50 billion of market value by 2030 (Bell et al., 2018). It is also expected that the biobased industries could help create one million new jobs by 2030 (Bioeconomy Strategy, 2018). Responsibles of the European Commission (EC) (2018) recently stressed that the EU must accelerate the pace in switching industry production to renewable climate-neutral biobased resources having disclose of a $€ 100$ million circular bioeconomy thematic investment platform for risk sharing with developers of biobased solutions.

\subsection{Biobased materials and biotechnologies for eco-efficient construction}

So although the future of humanity remains shadowed by serious environmental challenges like those mentioned in the beginning of the previous section, one thing is sure that the construction industry will continue to grow due to an increase in the world population that by 2100 will hit the staggering number of 11 billion. A recent report-Global Construction 2030-forecasts that the volume of construction output will grow by $85 \%$ to $\$ 15.5$ trillion worldwide by 2030 , being that China, United States, and India will be responsible for 57\% of all global growth and the construction market in India will grow almost twice as fast as China to 2030 (GC, 2015). In this context the use of biobased construction materials plays a crucial role in order to reduce the environmental footprint of the construction industry. Biobased materials such as timber have been used in the construction industry for a long time especially as structural materials. Unfortunately, in the last century they show to be unable to compete with the higher performance of steel or reinforced concrete in ever higher skyscrapers. However, in the last couple of years the imperative of sustainable development has started to change that. And the science community has also engaged in contributing to the revival of biobased materials. With initiatives such as the COST Action FP1303, performance of biobased building materials has run from October of 2013 until October 21, 2017. Having among others an up-to-date review of the status of various biobased materials and the factors influencing their in-service performance (Jones and Brischke, 2017) have been published. More recent studies have also shown the increased importance of biobased materials. Pittau et al. (2018) recently showed that storing carbon in fastgrowing biogenic materials is much more efficient than that in timber elements. Pittau et al. (2019) studied the effect of storing carbon in biobased construction products when used for the renovation of existing facades having concluded that fast-growing biobased materials have a higher potential to act as a carbon sinks, compared to timber.

A different branch of biobased materials that was not covered by the publication that came out of the COST Action FP1303 relates to those that are biotech based. Around $15 \%$ of the total Ordinary Portland cement (OPC) concrete production-a 
typical construction material that is the most used material on the Planet Earthcontains chemical admixtures to modify their properties, either in fresh or hardened state. Superplasticizers based on synthetic polymers include melamine, naphthalene condensates, or polycarboxylate copolymers in order to improve its workability, strength, and durability. However, those admixtures were provided by the exploration of the fossil fuel industry. An industry that faces the scarcity of petroleum resources (Sorrell et al., 2012) armed conflicts over oil reserves (Verbruggen and van de Graaf, 2013; Colgan, 2014), and most importantly the environmental disasters caused by oil spills like the 2010 BP owned Deep Water Horizon oil spill released approximately 780 million liters of crude oil on the Gulf of Mexico (Atlas, 2011). Since oil exploration is moving into ever-deeper water and into stormier and icier seas, it means increased potential risks. All the above clearly justifies the search for new and biodegradable polymers based on renewable feedstocks. Examples of biobased admixtures used in concrete include lignosulfonate, starch, chitosan, pine root extract, protein hydrolysates, or even vegetable oils. Be there as it may the fact is that investigations on the use of biopolymers in OPC are still scarce. Between the 10,000 Scopus referenced journal papers related to OPC and published since the year 2000, only less than $1 \%$ concern the use of biopolymers. Also although OPC and dry-mix mortars consume the majority of biopolymers, a great diversity of bio admixtures with well over 500 different products is now used by other building materials industry (Planck, 2003). Fig. 1.1 shows how publications concerning OPC composites containing biomaterials and/or bio admixtures evolve in an exponential pattern in the new millennium. It is worth mentioning that

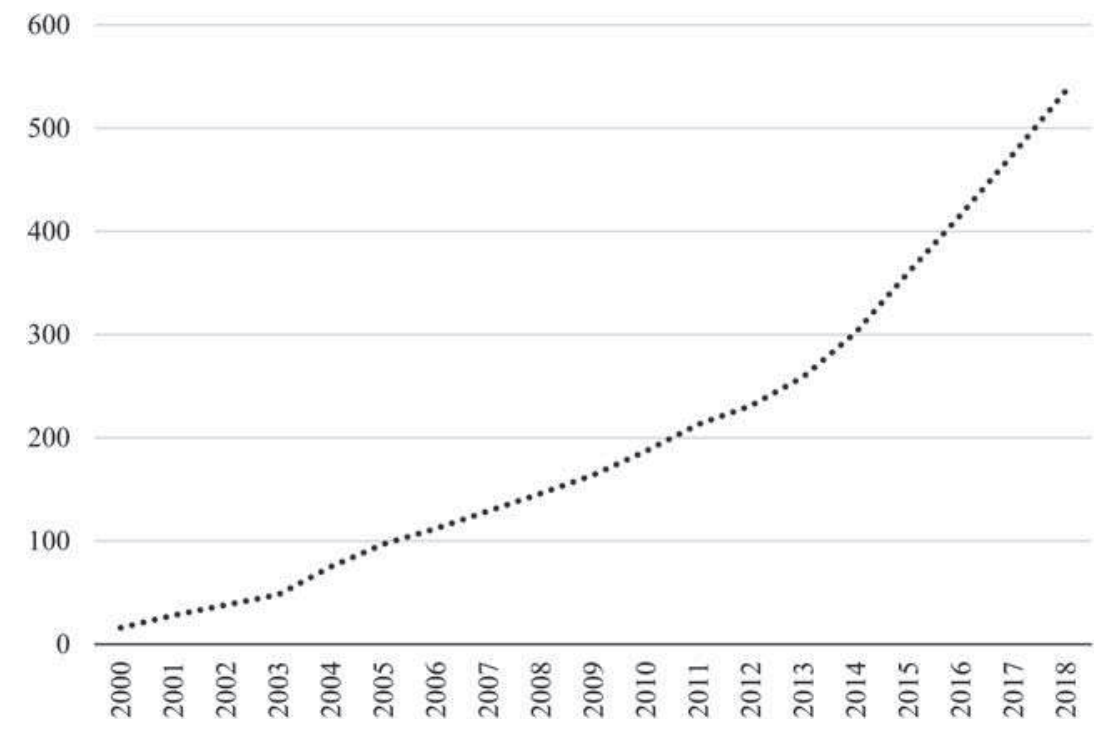

Figure 1.1 Evolution of the accumulated total number of publications related with OPC composites with biomaterials and/or bio admixtures.

Source: Data from Scopus. 
an innovative start-up found by marine ecologists, experts in urban marine ecology that developed bioenhancing concrete additives (ECOncrete, 2019) has recently been awarded by the European Commission (EC) (2019).

Biotech admixtures processes made in fermentation processes by employing bacteria (Luc and Eric, 2012; Pei et al., 2015) or fungi seem to receive increased attention, also because their biosynthesis rate is about two to four times higher than that of plant-based biopolymer (Ivanov et al., 2014, 2017). It is clear, however, that the farming practices used to grow biobased feedstocks, including the fuel required for plowing, harvesting, manufacture, transport, and the use of herbicides and pesticides, can also have high environmental impacts as high of petrochemical based polymers (Yates and Barlow, 2013). Still the reuse of agricultural and biomass waste will also contribute to enhance the environmental advantages of biopolymers over traditional petroleum-based polymers (Gopalakrishnan et al., 2012; 2013; Hottle et al., 2013). Bioresins based on polyfurfuryl alcohol produced from agricultural wastes have also recently been used with interesting results in civil engineering structural composites (Gkaidatzis, 2014). A widely technological solution for structural strengthening in civil engineering applications is based on carbon fiber reinforced polymers; however, not only they are expensive but also have a high environmental footprint, which explains why some authors (Viretto and Galy, 2018) are developing biobased epoxy matrices and also why Limaiem et al. (2019) recently studied the use of flax fiber reinforced polymer for the repair of damaged concrete and noticed that the new composites allowed not only enhancing properties of damaged concrete strength by $150 \%$, but also being associated to great ductility. Another important polymer widely used by the construction industry is polyurethane that is used in thermal insulation, as sealant, adhesive, in concrete jointing, and as protective coating (Somarathna et al., 2018). Still this polymer is obtained from isocyanates, known worldwide for its tragic association with the Bhopal disaster (Pacheco-Torgal and Jalali, 2011). In the last couple of years, however, many investigators have dedicated to the development of biobased polyurethanes. Gama et al. (2015) were able to produce polyurethane foams based on coffee ground wastes and Kurańska and Prociak (2016) presented a review on the production of rigid polyurethane foams for heat-insulating applications and Prociak et al. (2017) synthesized polyurethane using rapeseed oil.

The nanotech advancements that have occurred in the last decade will allow for the development of new and improved biopolymer-based materials. Investigations on cellulose nanocrystals (cellulose elements having at least one dimension in the $1-100 \mathrm{~nm}$ range) are an important and recent nanotech field that will enable the development of eco-efficient high performance materials (Charreau et al., 2013; Chirayil, et al., 2014). The potential of nanocellulose materials can be perceived from the increase in the number of papers published in this scientific field. According to Mariano et al. (2014) the number of papers in this area is expected to increase by a further $500 \%$ at least by 2017 , leading to an increase in perspective production in the range of $1000 \%$ in the next 2 years. Cellulose, being the most abundant organic polymer on the Earth, representing about 1.5 trillion tons of the total annual biomass production (Kim et al., 2015) renewable, biodegradable, 
carbon neutral, and having the potential to be processed at industrial-scale quantities at low cost, could become a green biotech source to future building materials. So far some investigations on the use of nanocrystalline cellulose to improve the modulus of elasticity of cement boards have already been patented (Thomson et al., 2010) and the cement industry has a potential nanocellulose market of over 4 million metric tons (Cowie et al., 2014). Cellulose aerogel is another promising application concerning the development of high performance thermal insulator building materials (Nguyen et al., 2014). High performance thermal insulators are materials with a thermal conductivity lower than $0.020 \mathrm{~W} / \mathrm{m} \mathrm{K}$, while current (petroleum based) insulator materials such as expanded polystyrene (EPS) and extruded polystyrene (XPS) have values around $0.03-0.06 \mathrm{~W} / \mathrm{m} \mathrm{K}$. This is a very important application just because the use of thermal insulation materials constitutes the most effective way of reducing heat losses in buildings, thus increasing its energy efficiency. Since aerogels are nonflammable, they do not release toxic fumes under fire as current insulation materials as EPS or XPS do (Pacheco-Torgal et al., 2012), which constitutes an extra advantage. Needless to refer that polystyrene, for example, contains antioxidant additives and ignition retardants, rather, its production causes the generation of benzene and chlorofluorocarbons. On the other hand, polyurethane is obtained from isocyanates that are widely known for their tragic association with the Bhopal disaster (Pacheco-Torgal et al., 2012). Besides, it releases toxic fumes when subjected to fire (Pacheco-Torgal et al., 2012).

Another important biotech feature for energy-efficient environment concerns the production of bioenergy through microalgae photo-bioreactors (PBRs) integrated in façades or roofs. Photosynthetic microalgae use sunlight as their energy, water as their electron source, and $\mathrm{CO}_{2}$ as carbon source. The use of microalgae for biofuel production goes back to the 1980 s and has gained increasing attention due to the need of renewable energies. Contrary to other biofuels sources, microalgae have high oil content and most importantly show an extremely rapid growth. It doubles their biomass within 24 hours being the fastest growing organisms in the world (Chisti, 2007). Microalgae cultivation can take place in raceway ponds or closed PBRs. The latter are less expensive to build and operate but have lower productivity when compared with PBRs. Those can include flat plates, vertical columns, stirred tanks, plastic bags, tubular, and even other configurations (Liao et al., 2014). Architectural PBRs are similar to the industrial ones and in the same way fulfill the function of cultivating microalgae; the innovation is its integration into architecture (Cervera and Pioz, 2014). Different types of microalgae with different colors, flat panel PBR with different algae concentration or with different water levels can provide dynamic shading for buildings. Buzalo et al. (2015) analyzed the problem of shape optimization of an architectural shell with photo-bioreactors using an algorithm that takes into account shading from neighboring buildings and provides the maximization of the specific growth of microalgae biomass.

Unfortunately, a divorce continues to exist between the fields of civil engineering and biotech research that is mostly conducted in biology and biotechnology departments. The fact is that biologists and engineers typically speak a very different language and create communication challenges. While biologists love to explore 
complexity, engineers excel at eliminating irrelevant complexity in order to build something that works and is fully understood (Pacheco-Torgal et al., 2015). Be there as it may and although interdisciplinary actions are necessary to solve complex problems (Nature, 2015), it is important to bear in mind the nature of the construction industry that is supported by a framework of legislation, regulations, case law, standards, contracts, professional practice, and research that establish the boundaries for acceptable performance. This is because the construction industry uses long warranty periods (which are very different from the $3-5$ years warranties used in the automotive industry); therefore, it is based on standard solutions (Sanjuan et al., 2011) that must have a solid proven record. A few years ago, I suggested some changes on the traditional civil engineering curriculum (PachecoTorgal, 2016) in order to form a new kind of professionals who not only had a much higher focus on environmental issues but were also able to engage in interdisciplinary efforts. That proposal was based on the civil engineering curriculum at the Imperial College London (ICL). In order to design the new curriculum, 15 new core moduli were incorporated on ICLs existent civil engineering MEng curriculum replacing some moduli that were deemed not to crucial (Table 1.1).

A module on biology and biotechnology basics was included on the first year, while a module on microbiology was suggested for the second year in order to help future practitioners of the construction industry to understand the language of their fellow colleagues from biology/biotechnology and to enhance future collaborations between the two areas. Of course since I made that curriculum proposal in 2016, a lot have changed in the world, including the fact that the pedagogy of degrowth has started to gain traction (Kaufmann et al., 2019) meaning that if that curriculum was to be suggested today, it would also need to address that major issue. And the same could be said concerning the "Deep Adaptation Agenda" (Bendell, 2019). Still 3 years after that proposal the currently broad picture shows that those two scientific areas still live a part. A Scopus survey on all the publications generated in civil engineering departments since the year 2000 shows that the words biology or biology represent just $9 \%$ of all the indexed publications. However, for the civil engineering departments of Tongji University (first position of ARWU ranking for civil engineering), that percentage is $4 \%$. Fortunately, other departments have started to have a different approach on this problem and while the percentage is $12 \%$ for TUDelft, it has much values for California, Berkeley (22\%), 31\% for the MIT, and $44 \%$ for the Swiss Federal Institute of Technology Zurich (second position of the ARWU ranking). And recent publications show innovative approaches on biobased construction (Heinrich et al., 2019). Of course we have to admit that somehow such low level of interdisciplinarity is also related to the fact that funding is mostly directed to classic areas (Bromham et al., 2016). As an important example of what was written above, let us take for instance the crucial health problem that concerns antibiotic resistance (Sansom, 2017); recently a team of experts from medicine and biotechnology (Mahnert et al., 2019) showed that increased confinement and cleaning is associated with a loss of microbial diversity that correlates with an increase in antimicrobial resistance, helping one to explain why people (especially older ones) living in certain built environments may have higher antimicrobial resistance. 
Table 1.1 Civil engineering MEng curriculum at the Imperial College London (ICL) and suggested core modulus for a curriculum on smart eco-efficient built environment.

\begin{tabular}{|c|c|}
\hline $\begin{array}{l}\text { Existent core modules at the civil } \\
\text { engineering curriculum at ICL }\end{array}$ & $\begin{array}{l}\text { Suggested core modules for an eco-efficient } \\
\text { environment undergraduate curriculum }\end{array}$ \\
\hline Year 1 & Year 1 \\
\hline $\begin{array}{l}\text { Professional engineering practice } \\
\text { Drawing } \\
\text { Surveying } \\
\text { Creative design } 1 \\
\text { Materials } \\
\text { Mechanics } \\
\text { Structural mechanics } \\
\text { Fluid mechanics } \\
\text { Geotechnics } \\
\text { Mathematics } \\
\text { Environmental engineering science } \\
\text { Computational methods I } \\
\text { Energy and infrastructure I } \\
\text { Introduction to civil engineering }\end{array}$ & $\begin{array}{l}\text { Professional engineering practice } \\
\text { Drawing } \\
\text { Creative design } 1 \\
\text { Materials for eco-efficient construction } 1 \\
\text { (new) } \\
\text { Mechanics } \\
\text { Structural mechanics } \\
\text { Fluid mechanics } \\
\text { Mathematics } \\
\text { Computational methods I } \\
\text { Nanotechnology basics (new) } \\
\text { Biology and biotechnology basics (new) } \\
\text { Smart built environment eco-efficiency (new) } \\
\text { Entrepreneurship skills (new) } \\
\text { Humanities and social sciences (new) }\end{array}$ \\
\hline Year 2 & Year 2 \\
\hline $\begin{array}{l}\text { Creative design II } \\
\text { Fluid mechanics } \\
\text { Structural mechanics } \\
\text { Soils and engineering geology } \\
\text { Environmental engineering } \\
\text { Statistics } \\
\text { Mathematics } \\
\text { Computational methods II } \\
\text { Structural design } \\
\text { Fluids design } \\
\text { Project and business management }\end{array}$ & $\begin{array}{l}\text { Structural mechanics } \\
\text { Soils and engineering geology } \\
\text { Statistics } \\
\text { Mathematics } \\
\text { Computational methods II } \\
\text { Structural design } \\
\text { Fluids design } \\
\text { Materials for eco-efficient construction } 2 \\
\text { (new) } \\
\text { Circular economy and life cycle analysis } \\
\text { (new) } \\
\text { Microbiology (new) } \\
\text { Humanities and social sciences (new) }\end{array}$ \\
\hline Year 3 & Year 3 \\
\hline $\begin{array}{l}\text { Structure and geotechnical projects } \\
\text { Structural mechanics } \\
\text { Fluid mechanics } \\
\text { Transport systems } \\
\text { Environmental engineering } \\
\text { Geotechnics } \\
\text { Computational engineering } \\
\text { analysis }\end{array}$ & $\begin{array}{l}\text { Structure and geotechnical projects } \\
\text { Computational engineering analysis } \\
\text { Apps for the smart built environment (new) } \\
\text { Low carbon building design (new) } \\
\text { Biomimetic and bioinspired design (new) } \\
\text { Nano and biotech applications (new) } \\
\text { Humanities and social sciences (new) }\end{array}$ \\
\hline
\end{tabular}


Table 1.1 (Continued)

\begin{tabular}{|l|l|}
\hline $\begin{array}{l}\text { Existent core modules at the civil } \\
\text { engineering curriculum at ICL }\end{array}$ & $\begin{array}{l}\text { Suggested core modules for an eco-efficient } \\
\text { environment undergraduate curriculum }\end{array}$ \\
\hline Dynamics & Start-up creation and Business Management \\
Optional 1 & $\begin{array}{l}\text { Optional 1 } \\
\text { Optional 2 } \\
\text { Optional 2 } \\
\text { The year ends with a 5-week group ends with a 5-week group design } \\
\text { design project. }\end{array}$ \\
\hline Year 4 & Year 4 \\
\hline Core modules & Core modules \\
Individual research project & Individual research project \\
Student conference (final activity) & Student conference (final activity) \\
Optional modules & Optional modules \\
\hline
\end{tabular}

Surely not by coincidence, one of the chapters on this book focuses on indoor quality and pollutant removal, including manipulation of microbial communities. And that is why this book may help one to bring more civil engineering departments to realize the potential of biobased and biotech research.

\subsection{Outline of the book}

This book provides an updated state-of-the-art review on biobased materials and biotechnologies for eco-efficient construction covering biobased materials and biotechnologies for infrastructure applications, for building energy efficiency and other applications.

The first part of the book includes biobased polymers, biobased asphalt, and nanocellulose coatings (Chapters 2-6).

Chapter 2, Biobased polymers for mitigating early- and late-age cracking in concrete, discusses carbohydrate-derived materials (i.e., fiber, biochar, and humins) regarding their sources, properties, production, and potential application in construction and building materials.

Chapter 3, Influence of two commercial superplasticizers and a biopolymer on the performance of waste-based alkali-activated mortars, reviews surveys, and discusses classes of natural polymers (i.e., polysaccharides and polypeptides) that have been used to create hybrid and biobased superabsorbent polymers (SAPs) and those that merit further exploration for use in cementitious materials. In addition, the potential for expanding the utility of SAPs, namely, exploiting SAPs for late-age crack mitigation, imparting multiple functionalities, and standardizing methods of their use in concrete, is highlighted and discussed herein.

Chapter 4, Fire-retardant bioproducts for green buildings, concerns a case study regarding the workability and compressive strength performance of a biopolymer 
against two commercial superplasticizers when using alkali-activated mortars based on fly ash and waste soda lime silicate glass.

Chapter 5, Properties of asphalt binder and mixture containing bio-asphalt derived from castor, discusses fire retardants, both traditional as well as biobased. Considerations on fire performance tests are included.

Chapter 6, Performance of biobased insulation materials in an old building envelope system, reviews studies on the performance of asphalt binder modified with castor oil, a vegetable oil made from the seeds of castor plant (Ricinus communis).

Biobased materials and biotechnologies for building energy efficiency are the subject of Part II (Chapters 7-13).

Chapter 7, Tilia sp.'s pruning residues wood panels for thermal insulation, provides an overview about the use of agricultural wastes on insulating materials. The source and characteristics of various types of wastes are described. The manufacturing processes considering the types of binders, including the main parameters involved are explained. An overview is given about the properties of the insulation materials, including thermal conductibility, density, mechanical strength, hygroscopic behavior, acoustic and fire performances, and environmental performance of these materials. Suggestions regarding the future research needs are also presented.

Chapter 8, Building insulation materials based on agricultural wastes, is concerned with the use of biobased insulation materials in an old building envelope system. The chapter includes both laboratory and on-site behavior of some biobased solutions.

Chapter 9, Properties of clay plasters with olive fibers, is dedicated to a case study that aims at the valorization of pruning wastes, of one of the most common tree species in urban greening and forestry: Tilia sp. (Linden tree), as building thermal insulation materials.

Chapter 10 focuses on the performance of building materials based on clay and on by-products of olive trees. It includes the main features of the used raw materials showing the physical and hygrothermal analysis. A hygrothermal simulation by WUFI plus software performed on a test building in a typical Mediterranean climate was also included.

Chapter 11, Biobased phase change materials, is dedicated to thermal insulation materials based on Hydrangea Macrophylla commonly known as "Hortensia" that is a shrub-like plant belonging to the Saxifragaceae family originating in Japan. The chapter shows the chemically, physically, and mechanically natural polymer characterization and two different ways of potential applications as building material.

Chapter 12, Building integrated photobioreactor, reviews biobased phase change materials (PCMs) and biomaterials-incorporated PCMs for accomplishing thermal energy storage and energy efficiency in buildings. The nucleus of the chapter is focused on the enhancement of thermal energy storage potential of a variety of biobased PCMs through the incorporation of different functional materials for the enhancement of energy efficiency in buildings.

In Chapter 13, Biotechnology for soil decontamination, microalgae and its growth cycle are explained briefly to give insight on their potential and limits for 
architectural applications. Also, systems to sustain habitat to these organizations are described. Alternative strategies for using these photo-bioreactors to benefit building environment, such as solar energy harvesting, carbon dioxide sequestration, wastewater treatment support, air quality enhancement, or dynamic façade applications are discussed.

Part III (Chapters 14-18) deals with biotechnologies for tackling pollution in soil, in water, in indoor air, and in infrastructure demolition waste.

In Chapter 14, Sustainable carbohydrate-derived building materials, various bioremediation approaches used for the degradation/removal of pollutants are described with an emphasis on microbial capacity and identification of specific bacterial communities, such as Bacillus sp. and Pseudomonas sp. The catabolic capacity of microorganisms is also discussed in detail to explain pollutants degradation processes in the soil.

Chapter 15, Botanical biofiltration for reducing indoor air pollution, looks at botanical biofiltration for reducing indoor air pollution. The main pollutants of indoor air quality are reviewed. Current solutions to tackle indoor air pollution are discussed. Biological solutions to address indoor air quality problems namely, passive systems, biotrickling filters, active botanical biofiltration, and functional green walls.

Chapter 16, Cellulose-TiO2 composites for the removal of water pollutants, provides an overview on the application of cellulose/titania composites for the removal of organic pollutants by heterogenous photocatalysis. The methods to pretreat cellulose and synthetize their corresponding titania composites are described in this chapter. The efficiency of the photodegradation of water pollutants is also analyzed as a possible application of these promising materials.

Chapter 17, Environmental safety of biotechnological materials and processes, covers environmental safety of biotechnological materials and processes. The chapter lists several cases of production and application of some biobased construction materials and processes that are unsafe for environment and human health. It also contains a list of biobased construction materials and processes that can be classified as bio safety as well as eco-efficient.

Chapter 18, Biotechnological immobilization of chemical, biological, and radioactive pollutants on land and infrastructure demolition waste after industrial accident, military action, or terrorist attack, closes Part IV with a review on biotechnological immobilization of chemical, biological, and radioactive pollutants on land and infrastructure demolition waste after industrial accident, military action, or terrorist attack

\section{References}

Atlas, R., 2011. Oil biodegradation and bioremediation: a tale of the two worst spills in U.S. history. Environ. Sci. Technol. 45 (2011), 6709-6767.

Bai, X., Dawson, R.J., Ürge-Vorsatz, D., Delgado, G.C., Barau, A.S., Dhakal, S., et al., 2018. Six Research Priorities for Cities and Climate Change. 
Bell, J., Paula, L., Dodd, T., Nemeth, S., Nanou, C., Mega, V., et al., 2018. EU ambition to build the world's leading bioeconomy - uncertain times demand innovative and sustainable solutions. New Biotechnol. 40, 25-30.

Bendell, J., 2018. Deep adaptation: A Map for Navigating Climate Tragedy. Institute for Leadership and Sustainability (IFLAS) Occasional Papers Volume 2. University of Cumbria, Ambleside, UK. <http://insight.cumbria.ac.uk/id/eprint/4166/1/ Bendell_DeepAdaptation.pdf $>$.

Bendell, J., 2019. Because it's not a drill: technologies for deep adaptation to climate chaos. Connect University Conference on Climate Change, 13 May 2019. DG Connect, European Commission, Brussels, Belgium, <http://insight.cumbria.ac.uk/id/eprint/4776/>.

Bioeconomy Strategy, Innovating for Sustainable Growth: A Bioeconomy for Europe, 2012. $<$ https://ec.europa.eu/research/bioeconomy/pdf/official-strategy_en.pdf $>$.

Bioeconomy Strategy, Updated Bioeconomy Strategy, 2018. <https://ec.europa.eu/knowledge4policy/publication/updated-bioeconomy-strategy-2018_en>.

Bromham, L., Dinnage, R., Hua, X., 2016. Interdisciplinary research has consistently lower funding success. Nature 534 (7609), 684

Bruntland G., 1987. Our common future, The World Commission on Environment 1 and Development, 45-65.

Buzalo, N., Ermachenko, P., Bulgakov, A., Schach, R., 2015. Photobiological treatment plants integrated with building's architectural shell. In: ICSC'15, The CSCE International Construction Specialty Conference, Vancouver, pp. 443-449.

Cervera, R., Pioz, J., 2014. Architectural bio-photo reactors: harvesting microalgae on the surface of architecture. In: Pacheco-Torgal, F., Labrincha, J., Diamanti, M., Yu, C.-P., Lee, H.K. (Eds.), Biotechnologies and Biomimetics for Civil Engineering. Springer, London, pp. 163-180.

Charreau, H., Foresti, M., Vazquez, A., 2013. Nanocellulose patents trends: a comprehensive review on patents on cellulose nanocrystals, microfibrillated and bacterial cellulose. Recent Pat. Nanotechnol. 7, 56-80.

Chirayil, C., Mathew, L., Thomas, S., 2014. Review of recent research in nanocellulose preparation from different lignocellulosic fibers. Rev. Adv. Mater. Sci. 37, 20-28.

Chisti, Y., 2007. Biodiesel from microalgae. Biotechnol. Adv. 25, 294-306.

Colgan, J., 2014. Oil, domestic politics, and international conflict. Energy Res. Soc. Sci. 1, $198-205$.

COM, 2011a. 571. Roadmap to a Resource Efficient Europe. European Commission, Brussels.

COM, 2011b. 21. A Resource Efficient Europe. European Commission, Brussels.

Cowie, J., Bilek, E., Wegner, T., Shatkin, J., 2014. Market projections of cellulose nanomaterial-enabled products-Part 2: Volume estimates. TAPPI J. 13, 57-69.

Davis, M., Faurby, S., Svenning, J.C., 2018. Mammal diversity will take millions of years to recover from the current biodiversity crisis. Proc. Natl. Acad. Sci. U.S.A. 115 (44), $11262-11267$

Domenech, T., Bahn-Walkowiak, B., 2019. Transition towards a resource efficient circular economy in Europe: policy lessons from the EU and the member states. Ecol. Econ. $155,7-19$.

European Commission (EC), 2018. <https://european-biotechnology.com/up-to-date/latestnews/news/eu-set-to-speed-up-switch-to-bioeconomy-by-new-action-plan.html >.

European Commission (EC), 2019. EU Prize for Women Innovators 2019. <https://ec. europa.eu/info/research-and-innovation/funding/funding-opportunities/prizes/eu-prizewomen-innovators/eu-prize-women-innovators-2019_en > . 
ECOncrete, 2019. <https://econcretetech.com/about/>.

Ekins, P., Hughes, N., 2017. Resource Efficiency: Potential and Economic Implications - A Report by the International Resource Panel (International Resource Panel Report) United Nations Development Programme, Nairobi.

EU, 2002. European Commission. Life Sciences and Biotechnology, a Strategy for Europe. Communication from the Commission to the European Parliament, the Council, the Economic and Social Committee and the Committee of the Regions. European Commission, Brussels, 2002.

Gama, N.V., Soares, B., Freire, C.S., Silva, R., Neto, C.P., Barros-Timmons, A., et al., 2015. Bio-based polyurethane foams toward applications beyond thermal insulation. Mater. Des. 76, 77-85.

GC, 2015. Global Construction 2030. < https://www.ice.org.uk/ICEDevelopmentWebPortal/ media/Documents/News/ICE\%20News/Global-Construction-press-release.pdf $>$.

Gkaidatzis, R., 2014 Bio-Based FRP Structures: A Pedestrian Bridge in Schiphol Logistics Park (Master thesis), TU Delft.

Gopalakrishnan, H., van Leeuwen, J., Brown, R., 2012. Sustainable bioenergy and bioproducts. Value Added Engineering and Applications. Springer.

Gopalakrishnan, H., Ceylan, H., Kim, S., 2013. Renewable biomass-derived lignin in transportation infrastructure strengthening applications. Int. J. Sustain. Eng. 6, 316-325.

Harrison, I., Abell, R., Darwall, W., Thieme, M.L., Tickner, D., Timboe, I., 2018. The freshwater biodiversity crisis. Science 362 (6421), 1369.

Heinrich, M.K., et al., 2019. Constructing living buildings: a review of relevant technologies for a novel application of biohybrid robotics. J. R. Soc. Interface 16, 20190238. Available from: < https://doi.org/10.1098/rsif.2019.0238>.

Hickel, J., 2019. Is it possible to achieve a good life for all within planetary boundaries? Third World Q. 40 (1), 18-35.

Holford, W.D., 2019. The future of human creative knowledge work within the digital economy. Futures 105, 143-154.

Hottle, T., Bilec, M., Landis, A., 2013. Sustainability assessments of bio-based polymers. Polym. Degrad. Stab. 98 (2013), 1898-1907.

Ivanov V., Chu J., Stabnikov V., 2014. Basics of construction microbial biotechnology, in: Pacheco-Torgal F., Labrincha J., Diamanti M., Yu C.-P. and Lee H. (Eds.), Biotechnologies and Biomimetics for Civil Engineering, Springer Verlag, London.

Ivanov V., Christopher L., 2017. Biorefinery-derived bioplastics as promising low-embodied energy building materials, in Nano and Biotech Based Materials for Energy Building Efficiency, Springer, Cham. pp. 375-389.

Jones, D., Brischke, C., 2017. Performance of Bio-Based Building Materials. Woodhead Publishing.

Kaufmann, N., Sanders, C., Wortmann, J., 2019. Building new foundations: the future of education from a degrowth perspective. Sustain. Sci. 14 (4), 931-941.

Kim, J.-H., Shim, B., Kim, H., Lee, Y.-J., Min, S.-K., Jang, D., et al., 2015. Review of nanocellulose for sustainable future materials. Int. J. Precis. Eng. Manuf. Green Technol. 2 (2), 197-213.

King, D., Browne, J., Layard, R., ÓDonnell, G., Rees, M., Stern, N., et al., 2015. A Global Apollo Programme to Combat Climate Change.

Kurańska, M., Prociak, A., 2016. Bio-based polyurethane foams for heat-insulating applications. Nano and Biotech Based Materials for Energy Building Efficiency. Springer, Cham, pp. 357-373. 
Liao, Q., Li, L., Chen, R., Zhu, X., 2014. A novel photobioreactor generating the ligth/dark cycle to improve microalgae cultivation. Bioresour. Technol. 161, 186-191.

Limaiem, M., Ghorbel, E., Limam, O., 2019. Comparative experimental study of concrete reparation with carbon epoxy \& bio-resourced composites. Constr. Build. Mater. 210, $312-323$.

Luc A., Eric P., 2012. Biodegradable polymers, in: Environmental silicate nanobiocomposites. Green energy and technology, Springer, Hiedelberg, pp 13-39.

Mahnert, A., Moissl-Eichinger, C., Zojer, M., Bogumil, D., Mizrahi, I., Rattei, T., et al., 2019. Man-made microbial resistances in built environments. Nat. Commun. 10 (1), 968.

Mariano, M., El Kissi, N., Dufresne, A., 2014. Cellulose nanocrystals and related nanocomposites: review of some properties and challenges. J. Polym. Sci. 52 (12), 791-806.

Nature, 2015. Why interdisciplinary research matters. Nature 525, 305. Available from: https://doi.org/10.1038/525305a. < https://www.nature.com/news/why-interdisciplinaryresearch-matters-1.18370>.

Nguyen, T., Feng, J., Ng, S., Wong, J., Tan, V., Duong, H., 2014. Advanced thermal insulation and absorption properties of recycled cellulose aerogels. Colloids Surf. A: Physicochem. Eng. Asp. 445, 128-134.

O’Neill, D.W., Fanning, A.L., Lamb, W.F., Steinberger, J.K., 2018. A good life for all within planetary boundaries. Nat. Sustain. 1 (2), 88.

Pacheco-Torgal, F., 2016. A proposal on a new curriculum for the smart eco-efficient built environment. The Sixth International Conference on Engineering, Mechanics and Computation. Taylor \& Francis, pp. 2175-2181.

Pacheco-Torgal, F., Jalali, S., 2011. Eco-Efficient Construction and Building Materials. Springer Verlag, London.

Pacheco-Torgal, F., Fucic, A., Jalali, S., 2012. Toxicity of Building Materials. Woodhead Publishing Limited Abington Hall, Cambridge.

Pacheco-Torgal, F., Labrincha, J.A., Diamanti, M.V., Yu, C.P., Lee, H.K. (Eds.), 2015. Biotechnologies and Biomimetics for Civil Engineering. Springer, Berlin.

Patermann, C., Aguilar, A., 2018. The origins of the bioeconomy in the European Union. New Biotechnol. 40, 20-24.

Pei, R., Liu, J., Wang, S., 2015. Use of bactéria cell walls as a viscosity-modifying admixture of concrete. Cem. Concr. Compos. 55, 186-195.

Pittau, F., Krause, F., Lumia, G., Habert, G., 2018. Fast-growing bio-based materials as an opportunity for storing carbon in exterior walls. Build. Environ. 129, 117-129.

Pittau, F., Lumia, G., Heeren, N., Iannaccone, G., Habert, G., 2019. Retrofit as a carbon sink: the carbon storage potentials of the EU housing stock. J. Clean. Prod. 214, $365-376$.

Planck, J., 2003. Applications of biopolymers in construction engineering. Biopolym. Online. 1, 29-39.

Prociak, A., Kurańska, M., Cabulis, U., Kirpluks, M., 2017. Rapeseed oil as main component in synthesis of bio-polyurethane-polyisocyanurate porous materials modified with carbon fibers. Polym. Test. 59, 478-486.

Ramcilovic-Suominen, S., Pülzl, H., 2018. Sustainable development-a 'selling point' of the emerging EU bioeconomy policy framework? J. Clean. Prod. 172, 4170-4180.

Randers, J., Rockstrøm, J., Stoknes, P.E., Goluke, U., Collste, D., Cornell, S., 2018. Achieving the 17 sustainable development goals within 9 planetary boundaries. EarthArXiv 2, 1-12. 
Read, R., 2018. This Civilisation is Finished: So What is to Be Done? < https://ueaeprints.uea. ac.uk/69557/1/Read_Rupert_This_Civilisation_is_finished_so_what_is_to_be_done.pdf $>$.

Sanjuan, M., Zaragoza, A., Agui, J., 2011. Standardization for an innovative world. Cem. Concr. Res. 41, 767-774.

Sansom, C., 2017. Antibiotic resistance: apocalypse soon? Lancet Infect. Dis. 17 (7), 706.

Schanes, K., Jäger, J., Drummond, P., 2019. Three scenario narratives for a resource-efficient and low-carbon Europe in 2050. Ecol. Econ. 155, 70-79.

Somarathna, H.M.C.C., Raman, S.N., Mohotti, D., Mutalib, A.A., Badri, K.H., 2018. The use of polyurethane for structural and infrastructural engineering applications: a state-of-theart review. Constr. Build. Mater. 190, 995-1014.

Sorrell, S., Speirs, J., Bentley, R., Miller, R., Thompson, E., 2012. Shaping the global oil peak: a review of the evidence on field sizes, reserves growth, decline rates and depletion rates. Energy 37, 709-724.

S. Schmidheiny with Business Council for Sustainable Development, 1992. Changing Course: A Global Perspective on Development and the Environment. MIT Press, Cambridge, MA.

Stoknes, P.E., Rockström, J., 2018. Redefining green growth within planetary boundaries. Energy Res. Soc. Sci. 44, 41-49.

Thomson, S.L., O'Callaghan, D.J., Westland, J.A., Su, B., 2010. Method of Making a Fiber Cement Board With Improved Properties and The Product US20100162926A1. <http:// www.google.com/patents/US20100162926>.

Verbruggen, A., van de Graaf, V., 2013. Peak oil supply or oil not for sale? Futures 53, $74-85$.

Viretto, A., Galy, J., 2018. Development of biobased epoxy matrices for the preparation of green composite materials for civil engineering applications. Macromol. Mater. Eng. 303 (5), 1700521.

WEO/IEA, 2017. World Energy Outlook 2017 Executive Summary. International Energy Agency, Paris.

Yates M., Barlow C., 2013. Life cycle assessments of biodegradable, commercial biopolymers-A critical review, Resources, Conservation and Recycling 78, 54-66.

Zubascu, F., 2019. How Much Money is in Your Trash Can? <https://sciencebusiness.net/ how-much-money-your-trash-can $>$.

\section{Further reading}

Albert, L.B., 1995. Ten Books on Architecture. Oxford University Press, London.

David, P.A., 2011. The innovation fetish among the economoi: introduction to the panel on innovation incentives, institutions, and economic growth. The Rate and Direction of Inventive Activity Revisited. University of Chicago Press, pp. 509-514, < https://www. nber.org/chapters/c12368.pdf >.

Morgan, A., Shaw-Brown, K., Bellingham, I., Lewis, A., Pearce, M., Pendoley, K., 2014. Global oil spills and oiled wildlife response effort: implications for oil spill contingency planning. In: International Oil Spill Conference Proceedings, vol. 2014, no. 1, May 2014, pp. 1524-1544.

Plank, J., 2004. Application of biopolymers and other biotechnological products in building material. Appl. Microbiol. Biotechnol. 66, 1-9. 
Soete, L., 2019. From "Destructive Creation" to "Creative Destruction": Rethinking Science, Technology and Innovation in a Global Context (No. 001). United Nations UniversityMaastricht Economic and Social Research Institute on Innovation and Technology (MERIT).

WCED (World Commission on Environment and Development), 1987. Report of the World Commission on Environment and Development: Our Common Future.

Yang, J., 2012. Intelligent Systems Analyzing Sections of the Great Wall of China for Ming and Pre-Ming Dynasty Construction (Electronic Thesis or Dissertation). Retrieved from $<$ https://etd.ohiolink.edu/ $>$. 